\title{
Globalisation and the Garment Industry in
}

\section{Sri Lanka}

Published in Journal of Contemporary Asia 2003 vol. 33 (2): 225-250

Hege M. Knutsen, University of Oslo

h.m.knutsen@sosgeo.uio.no

Department of Sociology \& Human Geography University of Oslo

P. O. Box 1096 Blindern

N-0317 OSLO Norway

Telephone: $\quad+4722855257$

Fax: $\quad+4722855253$

Internet: http://www.iss.uio.no/ 


\title{
Globalisation and the Garment Industry in Sri Lanka
}

\author{
Hege M. Knutsen*
}

\begin{abstract}
[Abstract: The objective of this article is to explain how globalisation, the phase-out of MFA and regionalisation affect the development of the garment industry in Sri Lanka. The article starts with a discussion of the key concepts of globalisation and regionalisation, followed by a presentation of the analytical framework, including a theoretical discussion of winners and losers in commodity networks. It is argued that regionalisation may exacerbate the problems that the Sri Lankan garment industry has already experienced in terms of globalisation. In addition to the limited industrial development effects that are the outcome of the functional division of labour, regionalisation makes it even harder to obtain market access. It is likely that Sri Lanka continues to be tied in, both to the European and American trading blocks for the production of some good quality and reasonably priced standardised garments for the middle market. However, to be tied in as a supplier of standardised products for the middle market is a vulnerable position, especially when the market is flat and lead firms and buyers in the network pass down adjustment costs to the suppliers. When manufacturers earn low levels of profits, the prospects of reinvestment in production and sustained industrial upgrading are negligible].
\end{abstract}

The textile and garment industries are often referred to as typically global and footloose industries. They were in fact "...the first manufacturing industries to take on a global dimension" and "...the most geographically dispersed of all industries across both developed and developing countries" (Dicken 1998, p.283). Manufacture of textiles and garments shifted from Europe and the USA to Japan in the $1950 \mathrm{~s} ;{ }^{1}$ to the three East Asian NIEs, South Korea, Taiwan and Hong Kong, in the 1960s; ${ }^{2}$ and then to China, South East Asia, and Sri Lanka in the 1980s. Subsequently, in the 1990s Vietnam and Latin-American countries were included among the export-oriented manufacturers of garments. Although Asian countries still are the main suppliers of garments to the OECD, there are signs of increasing regionalisation of the garment industry. Intra-Asia trade is increasing. So is trade between North America and Latin Americal the Caribbean region. In addition, countries in Eastern Europe and the European rim, i.e. countries such as Tunisia, Morocco and Turkey, are becoming increasingly important suppliers to Western Europe (Gereffi 1994, 1999, Mortimore 1999).

The garment industry is not only the most rapidly growing sector of the manufacturing industry in Sri Lanka. During the last 10-15 years there has been a gradual upgrading of the garment industry from export-oriented production of simple budget clothes to exports of branded garments for the middle market and even for the more fashion-oriented high-end market. The garment industry received more than $40 \%$ of the investment in manufacturing in the 1980s and 1990s. This was to a large extent due to tariff hopping

*Dept. of Socilogy and Human Geography, University of Oslo

Journal of Contemporary Asia, Vol, 33 No. 2 (2003) 
by East Asian companies. In 1995 the garment industry employed 230,000 persons in 750 factories (Kelegama and Foley 1999). Exports of garments accounted for $50 \%$ of the total exports of merchandise from Sri Lanka in 1999. The process of regionalisation in the garment industry and the abolition of quota trade under the Multi Fibre Arrangements (MFA) and later the Agreement on Textile and Clothing (ATC) at the end of 2004, pose a challenge to the garment industry in the country. The largest market of exports of garments from Sri Lanka is the USA which accounts for about $60 \%$ of it in value. This market is almost exclusively a quota market. Another $34 \%$ are exported to the European Union (EU). With effect from $1^{\text {si }}$ March 2001, quota restrictions on exports of garments from Sri Lanka to the EU were fully abolished. Until then, about $25 \%$ of the exports to the EU had been under quota restrictions (Kelegama and Foley 1999, International textile briefs 2000, 2001, Monjack 2000, European Commission 2001).

The objective of this article is to explain how globalisation, the phase-out of MFA and regionalisation affect the development of the garment industry in Sri Lanka. Industrial development refers to application of more complex and capital-intensive technology and that the organisation of the production process becomes more sophisticated. For linkages to appear and the process to be sustained, the industry has to generate value that is reinvested in the industry and in the national economy. The factors that will be looked into in respect of the Sri Lankan garment industry are technological change, market access and backward and forward linkages in the textile and garment industry.

The article starts with a discussion of the key concepts of globalisation and regionalisation and what is the relationship between the phenomena. Then follows a presentation of the global commodity chains approach and the characteristics of commodity chains of the textile and garment industry according to Gereffi (1994, 1996a,b, 1999). Together this leads to a conceptual framework for the analysis and a theoretical discussion of winners and losers in commodity networks. The analysis of how the garment industry in Sri Lanka experiences the processes of globalisation, the phase-out of MFA and regionalisation is carried out against the backdrop of changes in the spatial and functional division of labour internationally. Knowledge of globalisation and regionalisation processes in the garment industry internationally is important in order to discuss the outcome of it in Sri Lanka.

A case study research strategy is applied where primary data based on semi-structured interviews with open questions art combined with literature and national and international statistics (Yin 1994). Interviews were made in 8 buying offices (described below), 4 garment factories, an institute of clothing ${ }^{3}$ technology, a branch association of the buying offices and a branch association of manufacturers. Data collection took place in September 2000. Five of the buying offices can be characterised as belonging to US based marketers and three of them to European marketers. However, with one exception both categories export both to Europe and the USA. One of the factories was part of a US network, one of a European network and two had a foot in both types of network. The study is theoretically informed. The data are not statistically representative and the aim is not to make empirical generalisations. The quality of the data is satisfactory in terms of reliability and validity. However, if resources had permitted, it would have been useful to interview at least one production unit serving each of the selected buying offices. Moreover, it was not possible to 
get interviews in any of the few buying offices representing East Asian companies.

\section{Globalisation and Regionalisation}

What globalisation is, whether it takes place and whether it can be considered a meaningful analytical category is still under debate. ${ }^{4}$ In a nutshell globalisation can be considered a multidimensional process that serves to compress the world (Axford 1995). Hence, one may differentiate between more types of globalisation, such as economic globalisation, political globalisation, social globalisation and cultural globalisation. In the following, globalisation is understood as a process and a tendency (Knutsen 1998) and the focus is on economic globalisation. A tendency is a process that moves in a certain direction due to its inner logic, but despite this inner logic it may be reversed. More tendencies may exist at the same time.

Economic globalisation is considered an economic restructuring response to the erosion of the fordist mode of mass production and mass consumption that started in the late 1960s/early 1970s (Munck 1988, Perez 1997). The electronics industry as a key input factor industry facilitates the functional changes that are characteristic of globalisation. Technological change made it possible both to decompose the production process and to co-ordinate and control dispersed economic activities.

Until recently neoliberals, such as Ohmae (1990) and Sachs (ref. in Aftenposten 16 Nov. 1997) tended to apply the terms globalisation and increasing internationalisation interchangeably. At present, however, more and more writers on globalisation stick to the distinction that internationalisation per se refers to dispersion of economic activities to more than one country, whereas globalisation refers to a more advanced form of internationalisation signified by "functional integration between internationally dispersed economic activities" (Dicken 1998). Functional integration means co-ordination and regulation that tie the economic activities together and globalisation is considered essentially a qualitative process (Dicken and Yeung 1999). Advances in computer technology facilitates co-ordination and regulation at distance. Sourcing is an example of a form of functional integration which is increasing. It refers to a relationship where a core firm (the one that sources, not necessarily the lead firm in a chain) buys semifinished or finished products from a supplier elsewhere and uses this as an input in its production or to its product range (Bergst $\varnothing$, Endresen, Knutsen 1998).

Regionalisation is defined as increasing intraregional patterns of economic activity, such as trade and investment and the degree of regionness of an area (Hveem 2000). Regionness varies by policy issue. Although regions are traditionally defined by shared characteristics, regional co-operation is advanced by social and political action (Higgott 1999). Regionalisation could simply be a an effect of production and trade decisions made by firms as a response to competition in general (Hveem 2000). In fact, regional firms and corporations have been the principal actors of regionalisation in East Asia (Higgot 1999). This is not to deny that the nature of competition and business decisions are affected by changes and differences in economic policies and political conditions between places.

Regionalism ${ }^{6}$ refers to an attempt at directing international activities to some political goal (Hettne 2000). A new wave of regionalism started in the mid-1980s. From 
an economic point of view, new regionalism of the neoliberal type is open. Preferential treatment is given within the region, but there is also selective openness to other regions and a balance between being closed and open to come to terms with multilateral regulations such as in the GATT/WTO.

Regionalism is one of more approaches to deal with global problems, and new regionalism can be considered a political corrective to adverse effects of economic globalisation. As a corrective to or modifier of globalisation, it can be a stepping-stone of globalisation or a stumbling-block of the whole process. This is in line with the process-tendency view on globalisation, i.e. that more tendencies may co-exist and that there are tendencies and counter-tendencies. Amin (1997, 2000) considers regionalisation ${ }^{7}$ something that can and should replace globalisation. He argues that deepening globalisation is a post 1945 phenomenon and that the world has been heading for global disorder and chaos since the 1990s. The regions should be self-reliant and an alternative to neoliberal globalisation. The argument is of the stumbling-block type. Mistry (2000), in contrast, implies that regionalism may facilitate economic globalisation of a positive type, i.e. with less adverse effects than is the case at present. This is a stepping-stone type of argument, although he holds that "..the world is inexorably becoming a single global market place, with or without regionalism." (p.151) The notion that there is not necessarily a direct causal and unidirectional relationship between regionalism and globalisation (Hettne 2000, Hveem 2000, Mistry 2000), is in sharp contrast to Ohmae (1990). He thinks that regionalisation, whether fuelled by regionalism or not, is an empirical manifestation of the fact that globalisation takes place and that regionalisation will grow until "full" globalisation is accomplished.

Globalisation sceptics argue that economic activities tend to be more regional than global in orientation (Ruigrok and van Tulder 1995, Hirst and Thompson 1996, Thompson 2000). Cross-border operations such as sourcing and intra-industry and intra-firm trade are mainly concentrated to the OECD countries. However, some Asian NIE-countries and China have become included in the globalisation processes. Moreover, Japan has become a major source of FDI and more OECD countries and first generation NIE countries have become sources of FDI. Although research and development are dispersed to Asia through foreign TNCs, the subsidiaries tend to lag behind their parent firms in terms of technology (Vickery 1996). This means that the actual geographical dispersion of the functional changes are restricted to a limited number of countries more precisely to the Triad of North America ${ }^{8}$; Europe; Japan and the NIEs.

In line with the process-tendency approach it nevertheless makes sense to speak of globalisation because tendencies (at the abstract level) may not yet, or ever, manifest themselves in a new order (at the concrete level) (Dicken, Peck and Tickell 1997). Moreover, the scope of the process is global because it affects locations and people that are not directly subject to the functional changes. According to Mittelman (2000), regionalism not only takes place as a response to globalisation, but is a component of it. There is no conflict between regionalism and globalisation because "...economic and political units are fully capable of walking on two legs." (p.25) Widening regionalism is a current tendency and in addition to the macro regions of the Triad, there are overlapping sub-regions 
(growth triangles) and micro-regions (within countries). Business networks are established both within and across regions. At the firm level advocates of the process-tendency approach agree with globalisation sceptics that few, if any, TNCs are truly global.

Functional integration is essential both to the concept of globalisation and regionalisation. The difference between the concepts of globalisation and regionalisation at the level of industrial organisation is that in the latter case the functional integration takes place within a defined geographical region. In the analysis below, the focus is on international regions, with the macro regions of the Triad as the point of departure. The debates over globalisation and regionalisation, raises the following question: to what extent and how is regionalisation of the garment industry a response to the outcome of economic globalisation in the same industry?

\section{The Global Commodity Chains Approach}

Gereffi et al. (1994) have developed the global commodity chains approach which is a tool to examine functional changes in the world economy and shifts in industrialisation on a world scale. It is also a tool to examine why some win and some lose in the functional division of labour.

A commodity chain has three dimensions. The first signifies the sequence of value adding activities that make up the final product. Each activity can be considered a node in the chain. Territoriality, which is the second dimension, refers to spatial concentration and dispersion of the activities. The third dimension is the power relations between the parties that interact (Gereffi 1994, 1996a,b). The dimension of value adding activities merely reflects economic linkages in terms of input-output structures. Sourcing is a key input-output activity that takes place in the commodity chain. It is, however, the dimension of power relations, which is sometimes referred to as governance structures of coordination and control, that make the input-output structure interesting. Power relations determine what activity is going to take place where; in what node of the chain surpluses are generated and/or appropriated; how much of the surplus is reinvested in what node; and what nodes cover adjustment costs when surpluses are low or zero. Territoriality in terms of place and location-specific factors, may affect power relations between the business interests that interact, for example through industrial policies and regulations on paper and various unwritten conventions and practices. The term commodity network is sometimes used interchangeably with commodity chains in literature (Korzeniewicz 1992). However, in order to speak of networks, the dimension of social relations between the parties that interact in the chain have to be added to the input-output dimension.

There are two main types of commodity networks, the producer-driven commodity network and the buyer-driven commodity network. In producer-driven commodity network big capital- intensive and technology-intensive firms that are producers themselves, control backward and forward linkages. In buyer-driven commodity networks the lead firms are retailers, designers and trading companies. They are "manufacturers without factories" (Gereffi 1996a, p. 82), that control and co-ordinate offshore production networks for labour intensive consumer goods. Buyer-driven commodity networks are typical to the textile and garment industry. In the textile and garment industry the 
input-output structure starts upstream at the raw materials end, i.e. either in production of cotton or in the chemical industry with production of synthetic fibres. Then follows the midstream spinning and weaving industry and the downstream garment industry. The accessory industry producing thread, labels padding, shoulder pads, buttons, hangers, cartons and poly-bags etc. represent backward linkages of the garment industry.

Organisation of data in input-output structures and the focus on territoriality and power relations is a useful analytical tool as it captures and describes the functional integration between internationally dispersed economic activities, i.e. what is increasingly becoming the common definition of economic globalisation. It is, however, in the nature of the power relations that govern the chains that one has to search for explanations as to whether inclusion in the chain supports or impedes development of an industry in a given geographical area. The input-output structures in a location are spatially embedded when they are rooted in local economic, social, political and cultural networks (Dicken, Forsgren \& Malmberg 1994). This happens when companies establish networks with partners in countries where they have some relations such as family, ethnic and language ties at the point of departure (Gereffi 1999). Spatial embeddedness makes the activities less vulnerable to increasing competition from outside.

Gereffi sticks to the concept of global commodity chains and networks although they may sometimes be more regional than global in orientation. Dicken, Peck and Tickell (1997) and Ruigrok and van Tulder (1995) introduce the concept of quasi-global or glocal strategies of firms. Firms with such strategies strive at a geographically concentrated inter-firm division of labour in one of the three trading blocks. This is in contrast to a global strategy where the aim is to attain a world-wide division of labour. To be able to explain the increasingly regional orientation of the garment industry that Gereffi $(1994,1996 a, b, 1999)$ and Mortimore (1999) point at, it is necessary to distinguish between different types of networks based on geographical orientation. The following will be distinguished between in the analysis: i) the global network with a worldwide functional division of labour and worldwide markets; ii) the quasi-global network with a functional division of labour which is geographically concentrated in a region but cater to extraregional markets, and iii) the regional network with an intraregional functional division of labour and intraregional markets.'

\section{Winners and Losers in the Network}

To be a winner in a network is a matter of being able to attain sustained competitiveness. Competitiveness refers to the ability to earn profits and to survive and grow in the market. Based on Schumpeter, competition implies that entrepreneurs search for new combinations in order to "escape the tyranny of the normal rate of profit" (Kaplinsky 2000), i.e. obtain profits above the average of the industry. Storper and Walker's (1989) distinction between weak and strong ${ }^{10}$ competition and Porter's (1990) distinction between competition in cost-leadership and quality/uniqueness in the market reflect this approach. Strong competition and quality/uniqueness in the market are based on the notion of new combinations. Whereas weak competition is competition in cost-leadership, strong competition refers to products for which customers are ready to pay premium prices. Strong competi- 
tion requires innovation and constant improvements of products and services related to the products. More importantly, quality does not only refer to durability and appearance. Trust and good relationships with the customers are required. "The producers are approaching each other both in terms of product and price. Competition will increasingly have to do with how customers perceive their suppliers" (Elsrud 1999, my translation) and how customers perceive the value of the product. Perceived value is a function of how the consumer experiences the buyer, the status of the brand-name and what this brand-name tells about the user of the product. However, in addition, knowledge on how and where the product is manufactured, i.e. practices of the manufacturing suppliers of the buyers, may affect the consumer's perceived value of the product. Defined this way, perceived value differs slightly from Klein's (2001) notion of conceptual value-added which "....means adding nothing but marketing." (p.14) The distinction between "real value" and "conceptual value-added" was brought up at the annual meeting of the US Association of National Advertisers in 1988. The point of departure was the notion that consumers tend to buy brands, not products, and hence it becomes increasingly important to produce images of brands as opposed to things in order to remain competitive.

The two competitive strategies of competition in cost-leadership on the one hand and quality/uniqueness on the other are generic, i.e. arch type, strategies. In practice firms rely on different degrees or combinations of competition in cost-leadership and quality/uniqueness. In order to unbundle this in analyses of competitiveness of firms and industries, Kaplinsky's categorisation of different types of economic rents is helpful (Gereffi 1999, Kaplinsky 2000). Rents are returns from scarce assets. Technology rents arise from technology for production of unique products and technology to attain costefficient production due to more advanced inputs and machinery than the competitors apply. Brand-name rents arise from brand-name prominence which in turn result from product differentiation and marketing. Product differentiation could be created by marketing only (images of the brands), but may also involve technological changes that make the product different physically speaking. Organisational rents accrue from the organisation of the production process, e.g. the just in time system, within the organisation. In contrast, relational rents are of the interorganisational types and accrue from management of and collective efficiency in the commodity chain. Strategic linkages and family ties may generate relational rents. Trade policy rents accrue from incentives and protection, and quota arrangements are a point in case in the garment industry.

According to Gereffi and Korzeniewicz (1994) lead firms from developed countries extract surplus value from the periphery by co-ordinating and controlling the links that tie the commodity chain together. During economic down-turns adjustment costs are passed down to the suppliers. To the extent that this impedes reinvestment in technological upgrading, it makes the suppliers more vulnerable to competition in the longer run. In the buyerdriven commodity chain high profits can be obtained by combining production of brandname products in low-cost countries with premium prices for the same products in high-cost countries. This way of organising production is most advantageous to the overseas buyers and middlemen in the buyer-driven chains (Gereffi 1994). This illustrates the point that firms which compete in quality/uniqueness also have to pay attention to cost level in order 
to eam profits above the average of the industry. The lead firm and co-ordinators benefit from relational rents and brand-name rents, while the suppliers may benefit from brandname rents unless this is not fully appropriated by the lead firm and co-ordinators.

The essence of Gereffi's later publications (1996a,b, 1999), is to elucidate that there are in fact possibilities for industries in buyer-driven chains to improve their role in the international division of labour and contribute to industrialisation in the domestic economy. What is special about buyer-driven chains, is that the lead firm does not manufacture goods that compete with the goods of its suppliers. Hence, in addition to securing market outlets for the suppliers, the lead firm may also be more willing to transfer advanced technology and upgrade its suppliers. The supplier may thus benefit from technological rents. In a broader perspective, Kaplinsky (2000) writes that barriers to entry in production have fallen and it is difficult to compete with countries such as China which has an abundance of well educated labour. From the angle of the lead firm: "The primary economic rents in the chain of production are increasingly to be found in areas outside production." (Kaplinsky 2000, p. 11) Accordingly, the lead firms have to base their profits on systemic efficiency, i.e. attain relational rents, by improving the efficiency of the individual links in the chain. This necessitates technological upgrading of the suppliers who in turn may earn technology rents.

Technological upgrading of the suppliers are most likely when the technological gap between the core firm and the supplier is small. It is then easier to collaborate and/ or ensure that technology which is transferred to the supplier is adequately absorbed. Moreover, the scope of technological upgrading is more likely when the products are unique and sophisticated. Constant upgrading is required to remain in the technological forefront. This contrasts sourcing of simple and standardised products for the sole purpose of cost-cutting. Upgrading of the supplier would in such cases be considered a waste of resources. In contrast, when the supplier has something the core firm does not possess, the supplier may bargain for transfer of more advanced technologies, better market access and higher shares of the value-added. On top of these factors, one has to take into consideration the local context which conditions the capability for suppliers to absorb new technology and for new linkages to occur and technology to diffuse. Particularly in Taiwan and South Korea strategic targeting by the state through an elaborate system of regulations and incentives has been essential to the industrial upgrading (Lall 1996). The point here is that the bargaining power of the suppliers is conditioned by local policies, regulations and unwritten conventions.

\section{Changes in the Spatial and Functional Division of Labour}

The international trade in textiles increased sevenfold from 1945 to 1975 in a period with little increase in the demand for such goods. Both industrial and developing countries entered the international market. Industrial countries rebuilt their textile and garment industry after World War II and the developing countries that had initially developed an inward oriented textile and garment industry became more export-oriented (Dickerson 1991). In strategies of industrialisation prescribing light consumer goods as the starting point, the textile and garment industry is ideal. A local market for such 
goods exists and entry barriers are low because it is possible to build on traditional crafts and thereby avoid expensive technology imports. Local supplies of raw materials are not required because transport of this is neither technically difficult nor expensive (Dicken 1992). The garment industry is difficult to mechanise and automate and can thus serve as a major employer in countries with abundance of cheap labour.

In line with the notion that economic globalisation is a form of restructuring response to the erosion of the fordist mode of production, globalisation of the textile and garment industry started in the late 1960s/early 1970s. According to Lipietz (1997) the crisis that gave rise to the erosion of the fordist mode of production started as a demandside crisis when production and markets internationalised (my italics) in search for economies of scale in the 1960s. This fits the experience of the textile and garment industry. After the World War II, gradually more nations became involved in the production of textile and garments and then also started to export some of it. As a result of this, manufacturers in the North experienced increasing competition from lower cost manufacturers and responded by shifting production to lower wage locations both in the home country and to foreign countries (Spinanger 1992). Gradually the functional division of labour with networks of suppliers evolved.

Imports of cheaper textiles and garments to the countries in the North, resulted in close down of factories and loss of employment. Protectionist measures such as voluntary export restraints (VERs) were resorted to, and in 1962 agreements that restricted exports of cotton textiles from Japan, Hong Kong, Taiwan and South Korea to the UK and the USA were broadened into the Long Term Arrangement (LTA) within GATT. In 1960-1973, industry in Japan underwent a period of restructuring and scrapping. The industrial strategy based on exports of light consumer goods met with limitations. Trade friction arose with the USA and wages increased because employment was increasing. The solution was to make heavy industry the new target of the industrial strategy, and production of cotton textiles and synthetic textiles were shifted to other countries in East Asia (Hart-Landsberg and Burkett 1998). The first MFA replaced the LTA with effect from 1st January 1974. It included more countries in Europe than the LTA of 1962, and comprised textiles and garments of cotton and synthetic fibres (Gwynne 1990, Dicken 1992, Srinivasan 1996). The selective quantitative restrictions on imports that the MFA represents, contrast the principle of non-discrimination in the GATT rules. In 1995 the MFA was replaced by the ATC which is a ten year transitional programme for quota removal under the WTO (WTO 2000a).

Increasing cost competition in the garment industry signifies that the demand-led crisis was shifted into a supply-led crisis which in turn led to the introduction of MFA as means of protection of the garment industry in industrial countries. Cheap labour is not the only supply-side location factor manufacturers pay attention to. Educational level and the skills of the workers are taken into consideration, as well as advantages offered by the host country such as cheap loans, tax holidays and cheap infrastructure, and last but not least trade arrangements such as access to quotas and the General System of Preferences (GSP). " Moreover, competitive pressure differs somewhat between product groups. Technical competence, access to skilled workers and nearness to the market matter more for high quality fashion products than do low costs of production. 
Quota hopping as a response to the MFA and the fact that it became easier to transfer relevant technology to production units in the South, are two trends that contributed to the geographical dispersion ("stretching") of the garment industry. However, social networks, such as ethnic and family ties, common language and historical legacy conditioned where production was shifted to (Gereffi 1996a). Regarding functional characteristics of economic globalisation ("deepening"), FDI is far less prevalent than international sub-contracting, sourcing, licensing and other forms of non-equity involvement in the garment industry (Dicken 1992). The system of triangle manufacturing was initiated in the 1970s and 1980s as a response to increasing protectionism in the North. The essence of triangle manufacturing is that buyers from the North place orders with the three East Asian NIEs who in turn source products from manufacturers in developing countries to take advantage of their quotas and/or lower wage level. The buyers in the North have confidence in the three East Asian NIEs in the role of being "middlemen" or co-ordinators of the garment trade. They have a history of importing garments from the three East Asian NIEs and the latter have both the necessary technical knowledge as far as product quality is concerned, and knowledge about the cultural and social context in the countries that they source from. Buyer-driven chains, mainly of the quasiglobal type developed. The coordinating core companies sourced within their own region, but catered to extraregional markets. Big US and European marketers are the lead firms of the buyer-driven commodity chains. Since the mid-1980s, the market power of the US marketers has increased considerably (Gereffi 1999).

Sourcing and other forms of non-equity involvement are still on the increase. Although Asian countries, and particularly China and the East Asian NIEs, account for large shares of imports to the USA and Europe, authors such as Gereffi $(1996 a, b, 1999)$ and Mortimore (1999) hold that the buyer-driven commodity chains become increasingly regional in orientation throughout the 1990s. First, the three East Asian NIEs establish their own brand-names of garments which are both produced and sold in Asia. This points in the direction of increasing intra-Asia trade. Second, Gereffi $(1996 \mathrm{a}, \mathrm{b})$ assumes that as more developing countries throughout the world are integrated in the garment commodity chain, US buyers prefer to buy directly from countries in LatinAmerica/ the Caribbean region instead of using companies in the East Asian NIEs as middlemen. Third, countries in Eastern Europe and at the European rim are becoming increasingly important suppliers to Western Europe.

Increasing regionalisation is an outcome of increasing competition in an industry with low elasticity in demand. Changes in fashion stimulates demand, and this means that the firms have to compete in differentiation. With 6-8 buying seasons a year, fashion changes fast. This requires higher flexibility and reduction of the production turnover time, which has to be achieved by higher efficiency in the network, a point raised by Kaplinsky (2000) above, and closer proximity to suppliers and market. With the abolition of MFA, it becomes increasingly important to be able to compete in more than low prices. This stimulates flexibility and differentiation and thereby regionalisation. Demand for flexibility and shorter lead times ${ }^{12}$ could generate more growth within the region of Europe and its rim. The process of regionalism that has resulted in trading 
blocks is another cause of regionalisation of garment production. Duty and tax concessions make the products more competitive in price. This is important to the manufacturers whether competitiveness in price per se is the goal or whether the goal is to attain the right combination of "high quality and reasonable price." This is not to claim that regional commodity chains will fully overtake quasi-global and global chains. How pressed the firms are to reduce the production turnover time differs with type of products and how prone these are to changes in fashion. For example, production of expensive but less fashion-prone male suits, may still remain global.

To sum up, the MFA was a protectionist response to the internationalisation of the garment industry and increasingly tougher competition caused by economic liberalisation after the second world war. Triangle manufacturing in the 1970 s and 1980 s implies that the garment industry developed quasi-global characteristics. However, despite the globalist ideology of the 1980s and 1990s advocating free flows of trade and investments across national borders, there are signs that the garment industry becomes more regional than genuinely global in orientation with the phase out of the MFA.

\section{The Garment Industry in Sri Lanka}

Changes in Production: From 1956 to 1977 import substitution was the industrial strategy of Sri Lanka. With the election of the United National Party (UNP) in 1977, there was a shift to export orientation and establishment of EPZs. In the 1980s, triangle manufacturing included Sri Lanka in the global garment industry. The first EPZ to be initiated, was the Katunayake EPZ in 1978. Then followed Biyagama (1986), Koggala (1991), Minhintale (1993) and Kandy (1994). Almost all of the garment production is located close to Colombo, i.e. in the Colombo District, Gampaha District and Kalutara District. From November 1993 all garment enterprises are under the authority of the Board of Investment of Sri Lanka (BOI) and are subject to the same privileges as those in the EPZs. Among the advantages are duty-free inputs, low interest on credit, tax exemptions and reductions, and that enterprises are free to repatriate profits (Slater 1997, Kelegama and Foley 1999). The only advantage of being located in one of the EPZs, is the physical infrastructure (interviews). Some of the manufacturers hold that it is easier to get access to labour at a distance from the EPZs because there are then fewer companies to compete for the workers.

In 1970 and 1980 the share of the textile and garment industry ${ }^{13}$ of the industrial production accounted for $14 \%$ and $10 \%$ respectively. It reached $21 \%$ in 1984 and from 1990 to 1998 it increased from $32 \%$ to $44 \%$. The current value of production tripled from 1980-1984, and tripled again from 1985 to 1990 . In the period 1990-1998, the current value of production increased almost sixfold, and the value-added increased almost sevenfold (Central Bank of Sri Lanka in Karunatilake 1987, Central Bank of Sri Lanka 1987, 2000 internet).

In the early 1970s People's Bank granted loans to the establishment of four garment companies with Japanese collaboration. A few more companies came in operation in the period 1972-1977, and by the end of 1977 exports of textiles and garments amounted to Rs. 143 million $^{14}$ (interview, Central Bank of Sri Lanka 1982). Prior to 1977 exports were minuscule. From 1990 to 1998 the value of exports of textiles and garments qua- 
drupled from USD 628 million to USD 2460 million (in rupees the increase was sixfold from Rs. 25, 163 million to Rs. 159, 302 million) and accounted for $69 \%$ of industrial exports. In the late 1980s the share of garments in the export figures of textiles and garments was $99 \%$, but it has declined to about $90 \%$ in the 1990 s (Central Bank of Sri Lanka 1999,2000 ). Net export earnings from garments are $30-40 \%$ less the value of gross exports, reflecting that backward linkages in the country to production of textiles, trims and accessories are few. Industry representatives speak of a booming garment industry in the 1990s. It has come of age and does not manufacture the most basic items anymore. Despite the importance of the garment industry in the economy of Sri Lanka, Sri Lanka accounts for only $1 \%$ of world exports of garments (WTO 2000b).

The Network: Typical to the network in Sri Lanka is that a buyer from the USA or Europe set up a local buying office that it finances. The role of the buying office is to select the right suppliers in Sri Lanka, co-ordinate the orders and check the quality of production. Garment manufacture in Sri Lanka is of the cut, make and trim ${ }^{15}$ (CMT) type and the garment manufacturers are told where to purchase the fabrics. This is to ensure right quality and uniform products when garments are sourced from different manufacturers. Machinery is also imported, but it is not common to recommend and assist in purchases of this, except in cases where specialised machines are required.

Hong Kong is the selected regional hub of the network. As the US and European buyers tend to source from a large number of countries, it is common to have a regional co-ordinating office in Hong Kong that distributes the orders between the local buying offices and co-ordinates purchase and distribution of raw materials and accessories. Hong Kong is selected because of its close link to China where most of the buyers also source. Moreover, Hong Kong has the reputation of efficiency and a good business climate.

The product designs are developed in the USA and Europe and made available to the manufacturers by the local buying office. The buying offices have a staff of quality controllers whose role is to visit the factories and check the quality of production. Exports from Sri Lanka either take place on a free on board (FOB) basis or on a no foreign exchange (NFE) basis. In the latter case, the buying office purchases and provides the manufacturer with imported inputs. The very same buying office may offer the manufacturers either systems.

Collaboration with the manufacturing suppliers is based on trust. When new suppliers are approached, the buyers start with small orders. Some of the representatives of the buying offices were explicit that they always check on working conditions and wage level in addition to the quality of production before they select suppliers. This was verified by the suppliers. A study by the Centre for Research on Multinational Corporations (SOMO) ${ }^{16}$ and the Clean Clothes Campaign of five Dutch retailers, revealed that all of them have established a code of conduct and that they have started to implement it. However, the Clean Clothes Campaign emphasises that there is no sign of independent investigation of the working conditions in the factories, and that the workers do not think the codes of conduct have improved their situation in practice (Clean Clothes Campaign 2001).

The garment industry in Sri Lanka is not bigger than that the people involved know each other. This also means that the buying offices "know" who in the industry to select. Generally a buying office stay with the same suppliers for a long time and then gradually 
expand to new suppliers, but commitments are made on a batch to batch basis. The preference is to work with big and resourceful groups that have more factories. According to buyers and other industry representatives, it is easier for the big and resourceful to fulfil product quality requirements, meet larger orders and reduce delivery times.

Labour: It is no doubt that quota hopping coupled with a favourable cost level is the major reason for location of export-oriented garment industry in Sri Lanka after 1978. In the late 1970s labour costs in Sri Lanka were low for unskilled, semi-skilled and skilled workers (Vidanapathirana 1986). Cheaper labour was the case not only in comparison with Taiwan and South Korea, but also compared with India, Philippines and Malaysia. In a study of ten Asian countries, Sri Lanka was second only to Singapore in terms of productivity (Business Asia ref. in Vidanapathirana 1986). In addition, the whole garment industry enjoys the privileges of an EPZ-status (above). Sri Lanka ranks number 31 st of 40 countries in a list of hourly labour costs in the garment industry in 1995. The cost in Sri Lanka is USD 0.41. Among the nine countries with lower labour costs than Sri Lanka, are Indonesia (0.34), India, Pakistan and Vietnam (0.29), China (0.25) and Bangladesh (0.20) (ref. in Mortimore 1997). ${ }^{17}$ Manufacturers complain that skilled labour for the garment industry is no longer abundant in Sri Lanka (interviews), and that this forces the wages upward. Likewise, there is frustration about the fact that some US buyers require minimum wages before they place orders. It is, however, obvious that more factors than the wage level matters in making the industry competitive. One of the industry representatives claimed that it is more profitable to manufacture garments in the Middle East with wages three times the level in Sri Lanka. This is attributed mainly to the GSP, which is a source of trade policy rents.

According to interviewees in the buying offices, cheap labour is an important reason for sourcing from Sri Lanka. This is coupled with the advantage of a high level of literacy, the British background and skills in English, a favourable exchange rate, and honesty and seriousness of the suppliers. Only one of the interviewees in the buying offices complained about lack of responsibility among the suppliers. The western orientation of Sri Lanka politically and the export-led strategy of industrialisation are often mentioned as positive factors. When it comes to selection of countries and factories, manufacturers in Sri Lanka claim that they benefit from the fact that buyers want to diversify risks and not put all eggs in one basket.

Technology: "The technology "transfer" in the KIPZ (Katunayake Industrial Processing Zone) has largely been in lower level of technology in the garment field for which Sri Lanka had enough expertise even before setting up the Zone" (Vidanapathirana 1986, p.189, parenthesis added).

Since then there has not been any significant technological upgrading of the production process as far as machinery is concerned, generally speaking. The cost of automation is considered so high, that those who have the necessary resources, would rather invest in a business with higher returns. Manufacturers who complain that labour is becoming more expensive are also of this view. This is not to deny that there are some advanced specialised machines in the factories, for example for sealing of seams. One of the gar- 
ment manufacturers previously had a Korean counterpart that has withdrawn. Nowadays they buy fabric from the counterpart and get technical assistance when required.

Upgrading of product quality has taken place (above). Budget items account for $40 \%$ of production, the middle market for $50 \%$ and the upper market /fashion market for $10 \%$ (Ministry of Industrial Development ref. in Kelegama and Foley 1999, interview). The companies in the sample reported that they cater to the middle market and the fashion market. Through the buyers the manufacturers get access to new designs for more advanced products. The point raised by the manufacturers is to get access to brandnames. Product specifications and patterns are sent by e-mail to the manufacturers who make samples to prove that the factory is capable of making the piece in question, or they get a sample sent by courier that they have to copy. An indication of technology transfer is that the designs that the manufacturers get access to this way, often are applied in production for other customers the following season or year (interviews). In one of the factories it was mentioned that they have employed a designer because their European buyer asks for designs to be developed in Sri Lanka. Otherwise the interviewees held that the designs were developed in Europe or the USA.

The buying offices employ quality controllers who regularly visit the manufacturers, check the quality of the products and give advice. Quality controllers are good at pin-pointing mistakes. However, a buyer who caters to the upper-end of the market, complained that it is difficult to get hold of quality controllers who know how to assist the workers in correcting the mistakes. It is also a big challenge to move from the more systematic and regular quality control to quality assurance by spot checks. This implies that the skill level among the workers also could be better.

Two of the manufacturers in the sample had attained ISO 9002 certification. The ISO 9000 is a series of quality standards, where 9002 covers production and installation. The manufacturer has to define the quality standards and the steps required to conform to them. One of the manufacturers believed that the buyers prefer to give orders to ISOcertified manufacturers, but emphasised that it is difficult to measure the actual impact of it in the market. He added that they have to present good quality garments anyway. Another manufacturer held that the ISO-certification as such does not attract customers, but that it helps to improve the internal organisation of production. There is less waste of time and other resources, and this results in organisational rents. Some of the buyers stressed that their suppliers in Sri Lanka push themselves to upgrade in terms of product quality and organisation of production, and that they have reduced their lead time.

Rightly, garment manufactures in Sri Lanka earn more profits than before, but this is because they manufacture larger quantities. Profit margins dip lightly in spite of the upgrading of product quality. Technology rents and organisational rents for the manufacturers in Sri Lanka, accrue to foreign lead firms and co-ordinators as relational rents, and parts of the relational rents are absorbed by price reductions in the market. According to one of the manufacturers, prices have come down $20 \%$ the last two-three years, but investments to meet quality requirements are more expensive than before. Presently gross profit margins are claimed to be 10-15\%. According to Edwards (1996) the gross profit margin of six randomly chosen garment manufacturers in the Katunayake EPZ was $26 \%$ 
in 1989-1994. For all manufacturers in the zone, the average gross profit margin was $14 \%$ in 1990-1994. According to public statistics, profit margins vary considerably and were negative for the category of wearing apparel in 1983. In the early nineties it has varied from $30 \%$ in 1991 to $40 \%$ in $1992,50 \%$ in 1993 and minus $20 \%$ in 1994 (Slater et al. 1997). The latter was a year with labour unrest. In 1996 the profit margin was $30 \%$ (Department of Census and Statistics 1999). Profit margins are measured in terms of price-cost margins, and capital expenditures are not included in the figures.

Competitors, Lead Times and Backward Linkages: Both the representatives of the buying offices and the manufacturers referred to the garment industry in China, Mexico and in countries in Africa South of Sahara as the main competitors to Sri Lanka. China has the advantage of low cost of production in combination with good factories and good communication via Hong Kong. A representative of another buying office stressed that the customers are more concerned with price than quality, because quality is something everybody can attain. Monjack (2000) expects that a number of buyers will turn to China in the short run. Due to bureaucratic controls and delays, however, this may change in the longer run. China will mainly be attractive to those who source large quantities of items where price matters more than short lead times. This partly contrasts the preference of one of the buyers who cater to the upper end of the market. This company gets the more advanced garments manufactured in China, but the items are not among the most prone to sudden changes in fashion.

It was a common view in the buying offices, among the manufacturers and among other representatives of the branch, that lead times must be reduced and flexibility increased. Product development is something that takes place more slowly. The lead time today is about 100 days and it has to come down to 45 days. To be flexible implies that they have access to fabrics on a short notice to conform to the changing requirements of the buyers.

A representative of the association of buying offices expressed that backward linkages to the textile industry in Sri Lanka are required in order to reduce the lead times sufficiently. Other industry representatives hold that this is easier said than done. Sri Lanka does not cultivate cotton and does not have a petrochemical industry. Out of 140 textile mills in Sri Lanka today, less than ten account for the bulk of the output and only about $10 \%$ of the fabrics required for exports of garments are manufactured in Sri Lanka (Saheed 2000). ${ }^{18}$ Textile mills are costly to set up ${ }^{19}$ and quality yam is not easy to get. Countries such as India and Pakistan are not generally willing to export their raw material, but grey cloth is more easily accessible. The strategy of Mast Industries is to open a new printing factory in 2001 for fabrics of export quality. They will import large quantities of grey cloth in advance and are then able to print fabrics according to sudden changes in fashion and demand. Although it is difficult to mobilise capital to invest in textile factories in Sri Lanka, some facilities for manufacture of trims ${ }^{20}$ and accessories are established (Weerasinghe 2000).

Abolition of Quota Arrangements: All of the industry representatives expressed that they are pleased that the quota system is coming to an end. It is the manufacturers that hold the quotas. They claim that the quota allocation which is based on history is transparent and permissive, but that allocations of new quotas are problematic. Quotas become expensive 
when one has to buy from those who do not utilise them. They all agreed that competition will increase and only the fittest companies and factories will survive. Meanwhile, none of the manufacturers interviewed seemed to fear a close-down of their own units. Only one of the buying offices thought of moving business out of Sri Lanka.

Speaking of markets in the USA, manufacturers are concerned that quotas are going to be replaced by other types of regulations and requirements. More concretely they mention adherence to labour standards and minimum wage. Even nowadays they, i.e. particularly the US buying offices, check such conditions before orders are placed. Manufacturers also expect that some garments of US origin e.g. US fabric, will be required to get access to the US market. Survival after 2004 depends on a well established relationship with good buyers. This means buyers of high quality products with reputed brand-names and a focus on niche markets. Increased sales due to market access via brand-names, represents a potential for brand-name rents. However, manufacturers of items for some of the most exclusive brand-names are not permitted to tell about this and use it to attract more buyers in the high quality segment. This could be because the buyers fear that information that the product is manufactured in a low-cost country will harm the image of exclusiveness and thus reduce the perceived value of it. Representatives of the buying offices tend to think that the garment industry in Sri Lanka must automate, spend more money on technology and increase productivity in order to remain competitive. As mentioned above, manufacturers hold that the cost of automation is too high.

The representative of the entirely foreign owned factory, did not think that they would be seriously affected by increasing competition resulting from the abolition of quotas. The owner has more factories and cater to a big market. It is the owner and not a buying office that takes care of the marketing. So far, the factory in Sri Lanka exists in an environment protected by the owners, and has not felt the ups and downs in the market. At the time of the interview, they catered to the European quota market. Foreign staff, including a technical manager, are stationed in Sri Lanka. Because of the sunk costs such a factory represents to the owner, it may be more protected from competitive pressure and subsequent close-down than factories with less formal links with a buying office.

The EU Market: Despite the recent quota-free access to the EU market, this is not an easy market to compete in. Among suppliers of textiles and garments to the EU, Sri Lanka ranks number 20. Only a smaller part of Sri Lanka's trade in garments with the EU was subject to quotas before 1st March 2001 (above), and Sri Lanka competes in this market with countries in Eastern Europe that also enjoy quota-free entry. Internationally trade in garments almost stagnated in 1999 and this was mostly due to weak Western European trade (WTO 2000a). Moreover, Monjack (2000) refers to a study by the UK government that there will be zero growth in demand for ladies wear the next four years. Competition in price is tough. In 1998 the biggest retailer in the UK, Great Universal Stores, experienced $60 \%$ reduction in profits against "only" $10 \%$ reduction in sales. According to Monjack the retailers want to sell cheaper and thus they need to buy cheaper. At the same time it is essential for them not to risk large stocks of goods that do not sell as well as expected, and be able to maximise sales of styles that turn up to be in high demand. At 
present countries in Eastern Europe has a competing edge in this respect. Countries like Poland, Romania, Turkey, Bulgaria and Latvia have access to skilled labour which is almost as cheap as in Sri Lanka, and they have good factories with long experience in production of military uniforms and outdoor garments. Fabric prices have dropped because of tougher competition, and in Turkey fabric is not more expensive than in South Korea. When the fabric is sourced in Turkey and the garment made in Romania, it takes about four weeks from the time an order is placed to the time the garment reaches the market. In contrast it takes 12-16 weeks when the fabric is sourced in the Far East and the garment is made in Sri Lanka. Regarding the European market the advice to the Sri Lankan garment industry is to "produce value garments speedily and efficiently" (Monjack 2000, p.31). In order to be able to reduce lead times with 4-6 weeks, the recommendation is to produce good standard fabrics in Sri Lanka. In addition to the above mentioned problems with access to yarn and the high costs of capital involved in setting up textile factories, the recent agreement with the EU may represent an obstacle to upgrading of the textile industry. As part of the deal, Sri Lanka has reduced tariffs on imports of textiles and garments and agreed not to introduce non-tariff barriers on such items (EU 2000 internet).

The US market: In 1989,69\% of Sri Lanka's exports of garments (by value) went to the USA. The share declined throughout the 1990 s and in 1999 it was down to 60\% (Central Bank of Sri Lanka 1999, Resonance 2000). However, the quantity of Sri Lanka's exports of garments to the USA continues to increase. Competition in price is likely to be even more prevalent in the US market than the EU market. When the quota system is abolished, there will be no quota-added value on the prices any longer, and hence prices will fall (Monjack 2000). This implies reduction in a type of trade policy rents. The US buyers can demand lower prices because of the big size of their market segments and the large orders they place. One of the big US buyers with a buying office in Sri Lanka started with sourcing of products for the upper middle-income market and now expands to the moderate and mass market. Expansion in this direction means larger quantities of production and pressure on price. This is similar to how US types of networks operate in Mauritius.

Despite a demanding market, tight control and close cooperation with the buyer, inclusion in networks with US lead firms did not result in any technological upgrading to speak of in Mauritius. In the 1990s the country faced the challenge of full employment and wage rises. The cost of production increased and labour was difficult to recruit. At the same time the buyers demanded improved quality and considerably shorter lead time. ${ }^{21}$ The buyers tended to source increasingly more basic garments (simple and standardised) from lower cost locations; they restricted local sales in the host countries; and they required that the local manufacturers accepted longer terms of payment. Some organisational and technical changes were made by the manufacturers in Mauritius to speed up the production process in order to reduce the lead time. However, they still cater to the midmarket segment for private labels. In fact, some of the manufacturers even relocated to Madagascar as a response to sharpening price competition in the 1990s (Gibbon 2000).

Kelegama and Unamboowe (1994) have analysed potential consequences of NAFTA for the competitiveness of Sri Lanka's garment industry, focussing on the potential threat 
that Mexico represents. Their conclusion is that Mexico only poses a threat in fashion garments for the higher end of the market. Fabrics for the higher end fashion-oriented market are imported from the USA. The 6-8 buying seasons a year (above) and the proximity between the two countries give Mexico a competing edge in terms of shorter lead times. However, for the less demanding market segments, strict rules of origin within NAFTA are considered a disadvantage to Mexico. The rules imply that Mexico has to source fabrics from the USA. Most of the medium priced fabrics come from Hong Kong, South Korea and Taiwan, whereas India and China are sources of cheaper fabrics. Sri Lanka has the time and price advantage of being situated closer to cheaper suppliers of fabric for garments for medium and lower-end markets. Another factor in favour of Sri Lanka is that wage levels are higher in the garment industry in Mexico, and that labour productivity is not much higher than in Sri Lanka. An impediment to backward linkages in Mexico is that production costs in the textile industry are $25 \%-150 \%$ higher than in the USA, due to outdated technology and underutilisation of capacity. In addition, water scarcity is an impediment to textile dying. However, despite these disadvantages Mexico was the biggest supplier of garments to the USA in 1998 and US firms increasingly establish weaving and knitting plants near their customers in Mexico (Saheed 2000). Generally speaking, the representatives of the garment industry in Sri Lanka hold that higher quality, faster delivery and better prices are required to remain competitive in the garment industry (interviews). Based on this strategy Sri Lanka will have to compete with Mexico even in higher quality market niches, and with Caribbean Basin countries ${ }^{22}$ in types of cheaper products where short lead times matter. Where short lead times matter less, Sri Lanka meets sharp competition from China both in quality and price competition. Africa will be another force to reckon with in price competition.

The Caribbean Basin Trade Partnership Act (CBTPA) and The Africa Growth and Opportunity Act (AGOA) were signed in 2000 and are part of the US Trade and Development Act. It is claimed that due to trade and investment diversion to Mexico, resulting from the NAFTA agreement, more than 150 plants had to close in the Caribbean countries in 1995 and 1996 (Rother 1997 ref. in Gereffi 1999). With the inception of the NAFTA agreement in 1994 Mexico enjoyed lower tariff rates than the Caribbean Basin countries, quota-free imports to the USA of many types of garments and can apply Mexican inputs counting as NAFTA content in the production of garments. "The law (CBTPA) is intended to reflect the changing dynamics of regional trade which followed NAFTA ..... and to encourage the full participation of Caribbean Basin Countries in efforts to promote regional economic integration, including negotiations for a Free Trade Area of the Americas." (US Department of State undated. Parenthesis added) ${ }^{23}$ The USA permits duty and quota-free imports of garments from 24 eligible countries in the Caribbean Basin, provided it is made with US fabric and yarn. In addition, a country may import fabric made for knit garments from another country in the basin and then export the garments duty free to the USA. This is subject to an annual limit and only applies when the yarn is made in the USA. Duty and quota-free treatment for exports of garments to the USA is also granted when the fabrics in question are in short supply in the USA or the garment is hand-loomed, handmade or folklore article (US Department 
of State $2000 \mathrm{a}$, undated). It is expected that Caribbean Basin Initiative and the eventual Free Trade Area of the Americas are likely to increase intra-American trade in garments, and hence strengthen the process of regionalisation of the garment industry.

AGOA opens for duty free and quota-free access to the US market for garments made in sub-Saharan Africa of US yarn and fabrics; and garments made of yarns and fabrics not available or not manufactured in commercial quantities in the USA. In addition, duty and quota-free access is granted for garments made with African/regional fabric and yarn within limits ranging from $1.5 \%$ to $3.5 \%$ of the total value of US imports of garments. SubSaharan Africa countries with a GNP per annum of less than 1500 USD in 1998 can for four years get duty and quota-free access for garments made of third country fabrics. Thirtyfour countries are eligible for the benefits of $\mathrm{AGOA}$. To become eligible the countries are required to have market-based economies, develop political pluralism and rule of law, eliminate barriers to US trade and investment, protect intellectual property rights, make efforts to combat corruption, have policies to reduce poverty and increase availability of health care and educational opportunities, protect human rights and workers rights and combat the worst forms of child labour (US Department of State 2000b). This is similar to the eligibility requirement in CBTPA. It is expected that imports of textiles and garments from Africa will increase from USD 250 million a year to USD 4,000 million a year "over the length of this bill," i.e. by 2008 (US Department of State 2001). In comparison, Sri Lanka's exports of textiles and garments to the USA amounted to USD 1,404 million in 1997.

\section{Summary and Discussion}

The garment industry in Sri Lanka has experienced impressive growth rates as an export-led industry. Triangle manufacturing brought Sri Lanka into the global garment industry in the $1980 \mathrm{~s}$. However, nowadays the presence of co-ordinating firms from the first generation NIEs is less prevalent than expected. Several US and European lead firms have their own buying offices in Sri Lanka, which co-ordinate production and decide on the selection of suppliers there. The lead firms also tend to have regional offices in Hong Kong, which distribute production assignments among the various countries in the region. The type of networks that the manufacturers in Sri Lanka are involved in are mainly quasi-global. This is because material inputs are mostly obtained in Asia, i.e. the input-output relations of the production process are located in Asia. Designs are obtained from Europe or the USA and markets are in Europe or the USA.

This network-led type of industrialisation has led to some technological upgrading of the garment industry in Sri Lanka, mainly in the form of a movement up the ladder to higher quality products and more foreign private label and brand-name products. Unfortunately, the upgrading does not seem to have resulted in higher profit margins. The gradual abolition of MFA and the slow growing increase in demand for garments, lead to increasing pressure on price even for higher quality products. The lead firms need to maintain their profits and thus pass the burden down on their suppliers (Monjack 2000). ${ }^{24}$

The case of Mauritius shows how difficult it is for suppliers to establish their own private labels and brand-names in order to capture larger shares of this type of rent (Gibbon 2000 ). In the $1990 \mathrm{~s}$, manufacturers in networks with lead firms from the EU embarked on 
an offensive strategy of moving up the value chain from production of basic garments to fancy garments with either private labels or own brand-names. The strategy was unsuccessful, something that the manufacturers attribute to their underestimation of the time, knowledge and marketing skills that this requires ${ }^{25}$ The result was a return to manufacture of basic garments, with higher volumes of sale to customers in the mid-market segments. As in networks with US lead firms (above), there were manufacturers who relocated production to Madagascar as a response to the sharpening price competition.

Backward linkages to the textile industry in Sri Lanka are virtually absent and there are yet only few linkages to industries that provide trims and accessories. This is unfortunate as backward linkages reduce lead times which become more and more important in international competition. Internal factors such as lack of natural fibres and expensive capital compared with the present cost of labour can to some extent explain this (Kelegama and Foley 1999). More importantly, however, it is a paradox that dynamics of the networks can impede local backward linkages. Increasing competition in the textile and garment industry could mean that co-ordinators and lead firms in the commodity chains require (subtly) that the garment manufacturers import textiles made by firms and affiliates in the home countries of the lead firm, and that production-sharing agreements which inhibit backward linkages increase ${ }^{26}$ Three circumstances warrant this. First, production of fibres and textiles in Taiwan and South-Korea has increased over time. This has been stimulated by exports of textiles to manufacturers of garments in networks co-ordinated by companies from the two countries (Gereffi 1996a,b). Implicitly this opens for conflicts of interest over the location of backward linkages. Second, the NAFTA agreement and the CBTPA are means to prevent the shift in production of textiles and garments to Asia (above). CBTPA is considered likely to save US jobs and "create more markets for US goods," whereas Asian factories "would not use US textiles" (Manatt 2000). Third, in return for the recent quota-free access to the EU market, Sri Lanka has to open for textiles and garments exported from the EU.

The Caribbean Basin countries and Mexico were part of the US dominated network of textile and garment production already in the 1980s. NAFTA of 1994 and CBTPA of 2000 , result from regionalism which strengthens the on-going process of regionalisation. The region of Europe and its rim has its origin in the planned expansion of the EU coupled with the demise of communism and the fact that transitional economies in Eastern Europe have historical links with western European countries. In addition there is a history of co-operation between European countries and African countries in the Mediterranean area. Both the American region and the region of Europe and its rim can be characterised as regions of the trading block type. The US agreement with Africa South of Sahara and EU's agreement with Sri Lanka are ways of tying more distant geographical areas to the trading blocs.

US authorities hold that they want to promote economic development in Africa South of Sahara by combining trade and aid. This is important for security reasons, generally speaking, and is also a means to promote business opportunities for US investors. The EU granted Bosnia and Sri Lanka quota abolition in the garment industry at the same time. This should not be considered in isolation from EU's political role in peace keeping and peace negotiations in the two areas. CBTPA, AGOA and EU's initiative vis-a-vis Sri Lanka mean that quotas are cancelled and tariffs are cancelled or reduced. On the one 
hand, this is in line with the objectives of WTO, and only a few years ahead of the WTO deadline for quota abolition. The countries that get such deals with the USA and the EU have an opportunity to establish themselves more firmly in the market before the quota system is fully abolished. On the other hand, the contents of the CBTPA and AGOA agreements fit the expectations of the Sri Lankan industry representatives that quotas will be replaced with other and more subtle trade barriers. In contrast to the WTO notion of free flows of garments after the quota abolition, both CBTPA and AGOA clearly specify in which cases imports of garments which are not made with yam and fabric that originate in the US are permitted. In addition, the US Government through CBTPA and AGOA require compliance with internationally recognised workers rights. One may argue that the requirements pertaining to workers rights as expressed in CBTPA and AGOA are too general $^{27}$ to have serious implication on what countries and suppliers to select. It is however, a point to reckon with that trade unions in the USA and interest groups focus on working conditions abroad, and that this results in some pressure on the manufacturers. Buying offices that operate in Sri Lanka are concerned with their image, and suppliers in Sri Lanka already experienced that the buying offices check on their working conditions. Representatives of the garment industry in Sri Lanka claim that they will benefit from the combination of good quality products, reasonable prices and satisfactory working conditions when quotas are abolished. It is argued that transparency in terms of working conditions is better in a small country like Sri Lanka than in Bangladesh, Pakistan, Vietnam and China. Primary data on working conditions have not been collected from workers and unions in Sri Lanka. However, according to a recent study by SOMO and the Clean Clothes Campaign, workers complain that wages are too low, that there is a lot of obligatory overtime and that freedom of association is lacking (Clean Clothes Campaign 2001). ${ }^{28}$ In a study of the psychological impact of employment and living conditions of female workers in the free trade zones, Samarasinghe and Ismail (2000) also point at problems with work overload and low payment. Moreover, women complained about overcrowded dormitories and abuse or insults from inspectors, but there were also a few women in the sample who were satisfied with working conditions in the factories they worked for. The studies show that there is still a need to improve working conditions.

The fact that price competition becomes more severe together with the fact that buying offices interfere more than before with wage levels and working conditions, mean that manufacturers in larger business groups will be better equipped to survive the tougher competitive climate. The garment industry is expected to undergo a process of restructuring where small and less resourceful units will have to close down. To what extent improvements in working conditions will be an asset in competition for contracts with attractive buyers in the longer run, remains to be seen. There are examples that brand-name companies improve conditions in a country where they are in the spotlight, at the same time as they enhance their activities in countries where workers' rights are the least protected. ${ }^{29}$ No universal standard of corporate behaviour and system of enforcement are in place. On the contrary, a large number of different standards have been established. Many have been drafted by public-relations departments and are difficult to enforce (Klein 2001). This opens for competition on unequal terms. 


\section{Conclusion}

It makes sense to conclude that Sri Lanka's garment industry is squeezed by processes of globalisation and regionalisation. Regarding globalisation, functional integration in the network has not resulted in backward linkages that is crucial to reduce lead times and thereby become more flexible. The industry is vulnerable to price competition and it is difficult to get a good footing in competition in quality. This is because even the lower cost countries can manufacture garments of good quality and the lead countries in the North decide who will get access to the hottest designs and produce the highest quality items. The latter tend to be manufacturers with greater proximity to the markets with the highest purchasing power in the North. The need for shorter lead times stimulates regionalisation and Sri Lanka is situated far away from the two regions. Western orientation, both politically and in market orientation (garments), implies that Sri Lanka is not easily integrated in the Asian region either. In other words, regionalisation may exacerbate the problems already experienced in terms of globalisation. In addition to the limited industrial development effects that are the outcome of the functional division of labour, regionalisation makes it even harder to obtain market access.

When governments pursue regionalism, they stimulate freer trade which is mainly to enhance economies of scale and expand the market on the one hand. On the other hand, they protect their countries from some negative effects of freer trade, by shutting out extra-regional competitors. The process of regionalisation does not fully impede sourcing of standardised items from selected countries far away. Promotion of the latter may even be conducive to reach political goals. It is likely that Sri Lanka continues to be tied in, both to the European and American trading blocs for the production of some good quality and reasonably priced standardised garments for the middle market. This is because of the trust and relationships that have been built up over time and the need of the buyers to diversify risks, especially as long as bureaucratic problems may delay exports from lower cost locations. However, to be tied in as a supplier of standardised products for the middle market is a vulnerable position, especially when the market is flat and lead firms and buyers in the network pass down adjustment costs to the suppliers. Graduation into higher quality market segments is also likely to hit a ceiling. Perceived value linked to a brand-name is the essential ingredient in high quality pioducts. The production process of such high quality garments may require limited elements of specialised skills and knowledge. Hence, foreign owners of the brand-name appropriate most of the rents because they can bargain with a number of potential suppliers. When manufacturers earn low levels of profits, the prospects of reinvestment in production and sustained industrial upgrading in the host countries are negligible.

\section{Notes}

1. One should, however, note that Italy, the USA, France, Germany and the UK still belong to the top 15 exporters of garments in 1999 (WTO 2000a).

2. In Singapore the modern export-oriented garment industry was established in the 1960s by FDI from Hong Kong and Taiwan. Since then the investors have taken Singapore citizenship (Yue 1997).

3. The concepts of clothing and garments are applied synonymously.

4. References in Knutsen (1998), see also Held (2000). 
5. The process-tendency approach to globalisation is similar to the transformationalist approach referred to by Held $(2000)$.

6. This resembles Higgot's (1999) concept of de jure regionalisation which is government -led and based on institutional co-operation. However, Hettne (2000) and Mittelman (2000) touch upon the role of civil society.

7. Amin only applies the concept of regionalisation. He does not discuss the concept of regionalism at all.

8. Here North America refers to the countries who are part of the NAFTA-agreement: the USA, Canada and Mexico.

9. To speak of regional networks in the analysis is not to deny Mittelman's point (above) that regionalisation can be considered a component of globalisation. The point is to be able to identify and explain regionalisation processes in the garment industry.

10. The concepts of weak and strong competition builds on the assumption that the strategy of strong competition is the one which is more viable in the long run.

11. None or reduced duty on selected goods imported to industrial countries from selected developing countries.

12. Lead time refers to the time it takes from an order is placed to the product reaches the market.

13. The nomenclature is "textiles, wearing apparel and leather products." Production of the latter in Sri Lanka is negligible.

14. The figure refers to textiles and garments. Exports of textiles were negligible.

15. The verb to trim refers to finishing and decoration.

16. SOMO is a Dutch organisation.

17. The figures referred to in Mortimore (1999) include fringe benefits. The minimum wage in the garment industry in Sri Lanka was Rs. 110 per day or 2850 per month in 2000 . For more skilled workers, wages could range between Rs. 3400-3650 a month (documented in an interview). This does not include benefits.

18. About 200 million meters of fabric are manufactured per annum. Some 225 million meters are required for the domestic market and another 550-600 million meters for manufacture of garments for exports (Saheed 2000).

19. According to Kelegama and Foley (1999), it costs USD 20 million to set up a new knitting plant for production of 85000 meters a day and USD 15 million for a weaving plant producing 20 million metres of fabric a year. In comparison, it costs USD 0.8 million to set up a typical Sri Lankan garment factory with 200 sewing machines and 400 employees.

20. Examples of trims are sewing thread, hooks and eyes, snaps, buttons, lace trims, elastic strips and zippers.

21. For branded items, the lead time was reduced from 40 days to 21 days.

22. The Caribbean Basin refers to the countries of the Caribbean and Central America. North America refers to the USA and Canada as in the nomenclature of the WTO. Mexico is treated separately in the analysis, being the largest exporter of garments to the USA.

23. 7th April 2001, the ministers of trade of 34 countries on the American continent agreed to negotiate for the Free Trade Area of Americas by 2005 , and that the agreement shall be implemented before Ist January 2006 (Reuters ref. in Aftenposten 9th April 2001)

24. As expressed by Monjack, managing director of a London-based company with a buying office in Sri Lanka: "......all buyers are the same... they show no loyalty to their suppliers where money is concerned or profit is involved." And: "They need to maintain their profits and are ruthless in the way they do it" (Monjack 2000, p.26). The company is not a retailer, and it could be that he has retailers in mind when referring to buyers.

25. The problems of the manufacturers in the EU network were aggravated with the deterioration of the euro vis-a-vis the USD, because most of their raw materials were sourced from the US.

26. An example of this is the production-sharing mechanism of the US tariff code, HTS 9802, which allows USsourced garment inputs to be assembled offshore. Upon re-entry to the US tax is only paid upon the value added outside the US, which is mainly the cost of labour. Because the mechanism punishes generation of value added abroad, it is usually applied only where labour costs are low and few local components are required. Hence, it inhibits relocation of upstream stages of production and thereby prevents backward linkages and further development of the industry in the host country (Mortimore 1999). 
27. Eligiblity factors pertaining to workers: " 3 ) The extent to which the country provides internationally recognized worker rights, including - (I) the right of association; (II) the right to organize and bargain collectively: (III) a prohibition on the use of any form of forced or compulsory labor: (IV) a minimum age for the employment of children; and $(V)$ acceptable conditions of work with respect to minimum wages, hours of work, and occupational safety and health; and 4) Whether the country has implemented its commitments to eliminate the worst forms of child labor (USTR 2000).

28. The study was made among workers in factories that supply five well-known Dutch retailers.

29. Examples in Klein (2001).

\section{References}

Amin, S. (1997) Capitalism in the Age of Globalization (London: Zed).

Amin, S. (2000) Regionalization in Response to Polarizing Globalization in Hettne, B., Inotai, A., \& Sunkel, $O$. (eds) Globalism and the New Regionalism (London: Macmillan).

Axford, B. (1995) The Global System. Economics, Politics and Culture (Cambridge: Polity Press).

Bergst $\varnothing$, B., S. Endresen, \& Knutsen, H.M. (1998) Source and Hide Pollution. Industrial Organisation, Location and the Environment: Sourcing as a Firm Strategy. F-I-L Working Paper, No.14. Human Geography, Department of Sociology and Human Geography, University of Oslo.

Central Bank of Sri Lanka (1987a) Economic and Social Statistics of Sri Lanka, Vol. X, Colombo.

Central Bank of Sri Lanka (1987b) Annual Report, Colombo.

Central Bank of Sri Lanka (1999) Economic and Social Statistics of Sri Lanka 1999, Colombo.

Central Bank of Sri Lanka (2000) Socio Economic Data. http://www.lanka.net/centralbank update: 10/02/2000.

Clean Clothes Campaign (2001) Ethical Policies of Dutch Retailers. Newsletter 14 July. www.cleanclothes.org/ news

Department of Census and Statistics (1999) Annual Review of Industries 1997, Preliminary Report, Colombo.

Dicken, P. (1992) Global Shift, 2nd Edition (London: Paul Chapman).

Dicken, P., Peck, J., \& Tickell, A. (1997) Unpacking the Global. Lee, R. \& J. Willis. (Eds.). Geographies of economies. Arnold, London. 158-164.

Dicken, P. (1998) Global Shift, 3rd Edition (London: Paul Chapman).

Dicken, P.; Forsgren, F., \& Malmberg, A. (1994) The Local Embeddedness of Transnational Corporations in Amin, A. \& Thrift, N. (eds). Globalization, Institutions and Regional Development in Europe (Oxford: Oxford University Press) 23-46.

Dicken, P. \& H.W.C. Yeung (1999) Investing in the Future: East and South East Asian Firms in the Global Economy. In Olds, K., Dicken, P., Kelly, P.F, Kong, L. \& H.W.C. Yeung. (eds). Globalisation and the Asia-Pacific. Contested territories (London: Routledge).

Dickerson, K.G. (1991) Textile and Apparel in the International Economy (NY: Macmillan).

Economic Perspectives (1996) Trade Preference Programs, USIA Electronic Journals, Vol. 1, No. 11. Department of State. hittp.//usinfor.state.gov

Economic Perspectives (1998) US Western Hemisphere Trade Liberalization Initiatives, USIA Electronic Journals Vol. 3, No. 2. U.S. Department of State. http.//usinfor.state.gov

Edwards, C.(1996) The Uruguay Round and MFA Quotas: The Textiles and Garment Industries in Sri Lanka - The Next 10 Years, Research Studies Industrialization Series No. 4, Colombo: Institute of Policy Studies).

Elsrud, S. (1999) Helly-Hansen. Fra fjell, fjord og flagg til følelser, Magma, Tidsskrift for økonomi og ledelse. Vol.2, No.6.

European Commission (2001) EU Removes Textiles Quotas for Sri Lanka in Market Access Deal, Press release 1st March. http:/europa.eu.int/comm/trade/goods/textile

Gereffi, G., M. Korzeniewicz \& Korzeniewicz, R.P. (1994) Introduction: Global Commodity Chains in Gereffi, G. \& M. Korzeniewicz (eds), Commodity Chains and Global Capitalism (London: Praeger) 1-14.

Gereffi, G. (1996a) Commodity Chains and Regional Divisions of Labour in East Asia, Journal of Asian Business, Vol. 12, No.l.

Gereffi, G. (1996b) The Elusive Last Lap in the Quest for Developed-Country Status, Mittelman, $J$. (ed.). Globalization. Critical reflections (London: Lynne Rienner) 53-81. 
Gereffi G. (1999) International Trade and Industrial Upgrading in the Apparel Commodity Chain, Journal of International Economics, Vol. 48. 37-70.

Gibbon, P. (2000) "Back to Basics" Through Delocalisation: The Mauritian Garment Industry at the End of the Twentieth Century, Working Paper Subseries on Globalisation and Economic Restructuring in Africa. No. x. Centre for Development Research, CDR Working Paper 00.7, October.

Gwynne, R.N. (1990) New Horizons (New York: Longman).

Hart-Landsberg, M. \& P. Burkett (1998) Contradictions of Capitalist Industrialization in East Asia: A Critique of "Flying Geese" Theories of Development, Economic Geography, Vol. 74, No. 2. 87-110.

Held, D. (ed.) (2000) A Globalizing World? Culture, Economics and Politics (London: Routledge).

Hettne, B. (2000) Globalization and the New Regionalism, Hettne, B., Inotai, A., \& Sunkel, O. (eds), Globalism and the new regionalism. (London: Macmillan).

Higgot, R. (1999) The Political Economy of Globalisation in East Asia: The Salience of "Region Building." In Olds, K., Dicken, P., Kelly, P.F., Kong, L., \& H.W.C. Yeung. (eds), Globalisation and the AsiaPacific. Contested territories (London: Routledge).

Hirst, P. \& G. Thompson (1996) Globalization in question (Cambridge: Polity Press).

Hveem, H. (2000) Political Regionalism: Master or Servant of Economic Internationalisation? Hettne, B., Inotai, A., \& Sunkel, O. (eds). Globalism and the new regionalism (London: Macmillan).

International textile briefs (2000) European Union Lifts Restrictions on Sri Lankan Apparel Exports. Textileweb.com Date: 12/11/200.

International textile briefs (2001) EU Lifts Textile Trade Barriers for Sri Lanka, Bosnia. Textileweb.com Date: $2 / 26 / 2001$.

Jenkins, R. (1987) Transnational Corporations and Uneven Development: The Internationalization of Capital and the Third World (London: Methuen).

Kaplinsky, R. (2000) Spreading the Gains From Globalisation: What can be Learned From Value Chain Analysis. IDS Working Paper 110 (Sussex: Institute of Development Studies).

Karunatilake, H.N.S. (1987) The Economy of Sri Lanka, Centre for Demographic and Socio-Economic Studies, Colombo.

Kelegama, S. \& I. Unamboowe (1994) The North American Free Trade Agreement and Its Implications for Sri Lanka: With Special Reference to the Garment Industry, Research Studies, International Economics Series No. 2, Institute of Policy Studies, Colombo.

Kelegama, S. \& F. Foley (1999) Impediments to promoting backward linkages from the garment industry in Sri Lanka. World Development, Vol. 27, No. 8. 1445-1460.

Klein, N. (2001) No Logo (London: Flamingo).

Knutsen, H.M. (1998) Globalisation and International Division of Labour, Two concepts - One Debate?, Norwegian Journal of Geography, No. 3.

Korzeniewicz, M. (1992) Global Commodity Networks and the Leather Industry: Emerging Forms of Economic Organization in a Postmodern World, Sociological Perspectives, Vol. 35, No.2, 313-327.

Lall, S. (1996) Paradigms of Development: The East Asian Debate, Oxford Development Studies, Vol. 24, No. 2. 111-131.

Lipietz, A. (1997) The Post-Fordist World: Labour Relations, International Hierarchy and Global Ecology, Review of International Economy 4:1, Spring, 1-47.

Manatt, C.T. (2000) Byliner: Ambassador Manatt on Free Trade for Caribbean. Op-ed from The Wall Street Journal 04/11/00 (570). http://usinfo.state.gov

Mc Grew, A.G. (1992) Conceptualizing Global Politics, Mc Grew, A.G. \& P.G. Lewis. (eds). Global Politics: Globalization and the Nation State, (Oxford: The Polity Press).

Mistry, P.S. (2000) The New Regionalism: Impediment or Spur to Future Multilateralism? Hettne, B., Inotai, A., \& Sunkel, O. (eds), Globalism and the new regionalism (London: Macmillan).

Mittelman, J. (2000) Rethinking the "New Regionalism" in the Context of Globalization, Hettne, B., Inotai, A., \& Sunkel, O. (eds). Globalism and the New Regionalism (London: Macmillan).

Monjack, R. (2000) Speech at the Luncheon Meeting of the Sri Lanka Garment Buying Offices Association, 20 th January 2000, Resonance, No. 6.

Mortimore, M' (1999) Apparel-Based Industrialization in the Caribbean Basin: A Threadbare Garment? CEPAL Review 67. 119-136. 
Munck, R. (1988) Capital Restructuring and Labour Recomposition Under A Military Regime: Argentina (19761983) in Southall, R. (Ed.). Trade Unions and the Industrialization of the Third World (London: Zed Books).

Ohmae, K. (1990) The Borderless World. Power and Strategy in the Interlinked Economy (London: William Collins \& Co.).

Petrella, R. (1996) Globalization and Internationalization: The Dynamics of the Emerging World Order in Boyer, R. \& D. Drache. (Eds). States Against Markets, The Limits of Globalization (London: Routledge).

Porter, M.E. (1990) The Competitive Advantage of Nations. (London: Macmillan Press Ltd.).

Perez. C. (1997) The Social and Political Challenge of the Present Paradigm Shift. Paper prepared for the Norwegian Investorforum, based on the presentation at the Workshop Evolutionary economics and spatial income inequality. Oslo, May 15-16-1997. Norsk Investorforum 5/97.

Resonance (2000) Industry data, No. 6.

Ruigrok, W. \& R. van Tulder (1995) The logic of international restructuring (London: Routledge).

Saheed, A.H.H. 2000. Current status of Sri Lanka's textile and apparel industry and its global challenges. Resonance, No. 6 .

Samarasinghe, G. \& C. Ismail. 2000. A psychological study of blue collar female workers. Women's education and research centre, Colombo.

Slater, R., Chandrasin, S., Gunawardena, A. \& P. Parajasingham. 1997. The role of government in adjusting economies. Paper No. 15. The role of the state in business development: the case of the textile and garments sector in Sri Lanka. DAG Development Administration Group. The University of Birmingham, the University of London and the University of East Anglia.

Srininvasan, T.N. 1996. The Uruguay Round and Asian Developing Economies. Quibria, M.G.\& J. Malcolm Dowling. (eds). Current issues in economic development. An Asian perspective. ADB \& Oxford University Press, Hong Kong. 229-275.

Thompson, G. 2000. Economic globalization? Held, D. (ed.). A globalizing world? Culture, economics and politics. Routledge, London.

U.S. Department of State. 2000. International information programs. The United States -Africa Partnership. http./usinfor.state.gov./regional/af/trade/homepage. Update of March 01, 2000.

Spinanger, D. The impact on employment and income of structural and technological changes in the clothing industry. Van Liemt, G. (ed.). Industry on the move. ILO, Geneva.

Storper, M. and Walker, R. 1989. The capitalist imperative. Territory, technology and industrial growth. Basil Blackwell, New York.

UNCTAD. 1993. Trade and development report 1993. United Nations, New York.

U.S. Department of State. 2000a. Fact sheet: Caribbean Trade Partnership Act. 3rd Oct. 2000. http./I usinfor.state.gov

U.S. Department of State. 2000b. African Growth and Opportunity Act Implementation Guide. Oct. 2000. http.//usinfor.state.gov./regional/af/trade/homepage

U.S. Department of State. 2001. African Growth and Opportunity Act. Highlights. Ist March 2001. http.// usinfor.state.gov./regional/af/trade/homepage

U.S. Department of State. undated. Background information: Caribbean Basin Trade Enhancement. http.// usinfor.state.gov Downloaded March 2001.

Vickery, G. 1996. The globalization of investment and trade.(With Claudio Cassadio). De la Mothe, J. \& G. Paquet. (Eds.). Evolutionary economics and the new international political economy. Pinter, London. 83-117.

Vidanapathirana, U. 1986. Pattern of industrialisation: strategies and responses. Rusuputra, W. ef al. (eds). Facets of development in independent Sri Lanka. Lake House, Colombo.

Weerasinghe, E. 2000. Summary of speech given at the 7th annual meeting of the Sri Lanka Garment Buying Offices Association. Resonance, No. 6.

WTO. 2000a. Textiles: back in the mainstream. WTO trading into the future- agreements -textiles. http:l www. wto.org. Downloaded 6th March 2001.

WTO. 2000b. International Trade Statistics 2000. http://www.wto.org

Yin, R.K. 1989. Case study research. Design and methods. Applied social research methods series, vol. 5. Sage, London.

Yue, Chia Siow. 1997. Singapore. advanced production base and smart hub of the electronics industry. Dobson, W. \& Chia Siow Yue. (eds). Multinationals and East-Asian Integration. International Development Research Centre. Ottawa. 